\title{
Cytotoxic and Antitumoral Effects of Bikaverin Isolated from Gibberella fujikuroi on L5178Y Lymphoma Murine Model
}

\author{
Gabriela Hinojosa-Ventura ${ }^{1, *}$, Ana María Puebla-Pérez ${ }^{1}$, Martha Patricia Gallegos-Arreola ${ }^{2}$, Ma. del \\ Carmen Chávez-Parga ${ }^{3}$, Antonio Romero-Estrada ${ }^{4}$, Jorge Iván Delgado-Saucedo ${ }^{1}$. \\ ${ }^{1}$ Departamento de Farmacobiología, Centro Universitario de Ciencias Exactas e Ingenierías, Universidad de \\ Guadalajara, Guadalajara 44430, Jalisco, México. \\ ${ }^{2}$ Centro de Investigación Biomédica de Occidente, I.M.S.S., Guadalajara 44340, Jalisco, México. \\ ${ }^{3}$ Departamento de Ingeniería Química, Universidad Michoacana de San Nicolás de Hidalgo, Morelia 58030, \\ Michoacán, México. \\ ${ }^{4}$ Centro de Investigaciones Químicas, Universidad Autónoma del Estado de Morelos, Cuernavaca 62209, \\ Morelos, México.
}

*Corresponding author: Gabriela Hinojosa-Ventura, e-mail: ybag402_7@ hotmail.com Tel.: +52-3313785900

Received October 29 $9^{\text {th }}, 2018$; Accepted July $5^{\text {th }}, 2019$.

DOI: http://dx.doi.org/10.29356/jmcs.v63i4.729

\begin{abstract}
In this work, bikaverin was isolated from the mycelium of Gibberella fujikuroi and characterized using 1D $\left({ }^{1} \mathrm{H}\right.$ and ${ }^{13} \mathrm{C}$ ) and 2D (HSQC and HMBC) NMR spectroscopy. Its cytotoxic effect on L5178Y lymphoma cells and antitumor effect on BALB/c mice inoculated with L5178Y cells were evaluated. According to the results, bikaverin showed cytotoxic effect against L5178Y lymphoma cells with an $\mathrm{IC}_{50}$ value of 0.23 $\mu \mathrm{g} / \mathrm{mL}$. The tumor evolution, with and without treatment, was observed in the in vivo study; the group without treatment showed $1,280 \pm 128 \times 10^{5}$ cells $/ \mathrm{mL}$ in ascites volume, and the groups treated with bikaverin at the dose of $1.73 \mathrm{mg} / \mathrm{kg} / \mathrm{day}$ by intraperitoneal (i.p.) and oral administration, decreased significantly the cell density, and showed $391.5 \pm 237 \times 10^{5}$ cells $/ \mathrm{mL}$ and $580 \pm 208 \times 10^{5}$ cells $/ \mathrm{mL}$, respectively. The results confirm the cytotoxic effect of bikaverin on cancer cell lines and contribute to show the potential of bikaverin as antitumoral compound in BALB/c mice inoculated with L5178Y lymphoma cells.
\end{abstract}

Keywords: Gibberella fujikuroi; bikaverin; polyketide; cytotoxic and antitumoral effects.

Resumen. En este trabajo, se reporta el aislamiento de bikaverina a partir del micelio de Gibberella fujikuroi, cuya estructura fue elucidada mediante el uso de la espectroscopia de RMN en $1 \mathrm{D}\left({ }^{1} \mathrm{H}\right.$ y $\left.{ }^{13} \mathrm{C}\right)$ y $2 \mathrm{D}(\mathrm{HSQC}$ y HMBC). Se evaluó su efecto citotóxico en células de linfoma L5178Y y su efecto antitumoral en ratones $\mathrm{BALB} / \mathrm{c}$ inoculados con células L5178Y. De acuerdo con los resultados, la bikaverina mostró efecto citotóxico contra las células de linfoma L5178Y con un valor de $\mathrm{CI}_{50} \mathrm{de} 0.23 \mu \mathrm{g} / \mathrm{mL}$. En el estudio in vivo se observó la evolución del tumor, con y sin tratamiento, donde el grupo sin tratamiento mostró $1,280 \pm 128 \times 10^{5}$ células $/ \mathrm{mL}$ en el volumen de ascitis, y los grupos tratados con bikaverina a la dosis de $1.73 \mathrm{mg} / \mathrm{kg} / \mathrm{d}$ áa, administrada de forma intraperitoneal (i.p.) y oral disminuyeron significativamente la densidad celular, mostrando $391.5 \pm 237 \mathrm{x}$ $10^{5}$ células $/ \mathrm{mL}$ y $580 \pm 208 \times 10^{5}$ células $/ \mathrm{mL}$, respectivamente. Los resultados obtenidos confirman el efecto citotóxico de bikaverina sobre líneas celulares de cáncer y contribuyen a mostrar su potencial como compuesto antitumoral en ratones BALB/c inoculados con células de linfoma L5178Y.

Palabras clave: Gibberella fujikuroi; bikaverina; policétido; efecto citotóxico y antitumoral. 


\section{Introduction}

Cancer is one of the most important causes of death worldwide and is expected to rank as the leading in the 21st century. It is estimated that this disease caused 9.5 million deaths worldwide in 2018 [1]. Currently, there are many types of cancer treatment, but chemotherapy is one of the most widely used. However, because of the severe side effects exhibited by drugs used in the treatment of cancer and the drug resistance in tumor cells, novel agents and treatment strategies are necessary [2,3]. According to the Food and Drug Administration (FDA), 246 anticancer drugs were approved during the 1940-2014 period, around 38\% of which were natural products or derived from them [4]. In this context, one important source of bioactive secondary metabolites is fungi. This is supported by the various reports about secondary metabolites isolated from fungi. An example is the bioactive polyketide named bikaverin $\left(\mathrm{C}_{20} \mathrm{H}_{14} \mathrm{O}_{8}\right)$ [5-7]. This compound is produced by several fungal species, mainly from the genus Fusarium. Specially, it has been isolated from the G. fujikuroi (Fusarium fujikuroi) fungus $[8,9]$. Bikaverin has shown biological effects such as antiprotozoal, antifungal, nematicidal, and neuroprotective effect [10-13]. In addition, this compound has shown cytotoxic effect against different cancer cell lines at different concentrations [14-17]. For the current research, bikaverin was produced by $G$. fujikuroi fungus in a bioreactor under controlled conditions [18] and later isolated and characterized with the purpose of evaluating the cytotoxic effect against L5178Y lymphoma cells and the antitumoral effect on L5178Y lymphoma murine model.

\section{Experimental}

\section{Material and Methods Chemicals}

Penicillin-streptomycin, RPMI 1640 medium and fetal bovine serum were obtained from Gibco (Carlsbad, CA, USA). Cyclophosphamide, bikaverin standard, dimethyl sulfoxide (DMSO), silica gel 60, oxalic acid, chloroform, methanol, acetic acid, chloroform-d $\left(\mathrm{CDCl}_{3}\right)$ and trifluoroacetic acid-d $\left(\mathrm{CF}_{3} \mathrm{COOD}\right)$ were obtained from Sigma-Aldrich. The quick cell proliferation assay kit WST-1 was purchased from Biovision Inc., (Milpitas, CA, USA).

\section{Bikaverin Production, Extraction and Isolation}

Bikaverin was produced by G. fujikuroi fungus in a bioreactor under controlled conditions and extracted as previously described [18]. A sample $(210 \mathrm{mg})$ of ethyl acetate extract was subjected to normalphase column chromatography using a mixture (13 g) of silica gel 60:oxalic acid (95:05, w/w) and eluted with a mixture of chloroform:methanol:acetic acid (94:1:5, v/v/v). As a result, 40 fractions of $5 \mathrm{~mL}$ were collected. The fractions were monitored and compared with bikaverin standard by normal-phase thin layer chromatography. After this, the fractions with bikaverin were precipitated with methanol at $-70{ }^{\circ} \mathrm{C}$ during $24 \mathrm{~h}$, and $63 \mathrm{mg}$ of pure bikaverin was obtained.

\section{Spectroscopic Data}

Bikaverin was characterized by NMR in a Varian VNMRS (700 MHz) spectrometer at $700 \mathrm{MHz}$ for ${ }^{1} \mathrm{H}-\mathrm{NMR}$ and $175 \mathrm{MHz}$ for ${ }^{13} \mathrm{C}-\mathrm{NMR}$. The 1D $\left({ }^{1} \mathrm{H}\right.$ and ${ }^{13} \mathrm{C}$ ) and 2D-NMR (HSQC and HMBC) experiments were recorded in a mixture of chloroform-d $\left(\mathrm{CDCl}_{3}\right)$ and trifluoroacetic acid-d $\left(\mathrm{CF}_{3} \mathrm{COOD}\right)(1: 1, \mathrm{v} / \mathrm{v})$. Chemical shifts $(\delta)$ are expressed in parts per million (ppm) relative to TMS as an internal standard.

\section{Cytotoxic Assay}

The L5178Y lymphoma cells ( $5 \times 10^{4}$ cells/well) were seeded in a 96-well plate in $200 \mu \mathrm{L}$ of RPMI 1640 medium supplemented with previously inactivated $10 \%$ fetal bovine serum (FBS), $100 \mathrm{U} / \mathrm{mL}$ of penicillin and $100 \mu \mathrm{g} / \mathrm{mL}$ of streptomycin. After that, the cells were treated with different concentrations of bikaverin $(0.125,0.25,0.5,0.75$ and $1 \mu \mathrm{g} / \mathrm{mL}$ ) or vehicle (DMSO, $0.1 \%, \mathrm{v} / \mathrm{v})$ or positive control (cyclophosphamide at $11 \mu \mathrm{g} / \mathrm{mL}$ ) and incubated for $24 \mathrm{~h}$ at $37{ }^{\circ} \mathrm{C}$ in a humidified atmosphere containing $5 \% \mathrm{CO}_{2}$ [19]. The cytotoxic 
effect of bikaverin against lymphoma cells was determined by WST-1 assay, according to the instructions provided by the manufacturer. Briefly, $20 \mu \mathrm{L}$ of WST-1 solution was added to each well and incubated for $2 \mathrm{~h}$ under the same conditions. The optical density was measured at $540 \mathrm{~nm}$ in a microplate reader. The percentage of viable cells was determined by the following equation:

\section{Cell viability $(\%)=[$ Abs cells treated/Abs cells not treated $] * 100$}

The data generated was used to plot a dose-response curve which determines the inhibitory concentration (IC) 50 .

\section{In silico Toxicity Prediction}

Physicochemical and toxicity parameters were determined in an online screening tool for rodent oral toxicity prediction by PROTOX Software (http://tox.charite.de/tox). The prediction method was based on chemical similarity and identification of fragments that were over-represented in toxic compounds. Qualitative and quantitative data interpretation was released according to the instructions provided by PROTOX software $[20,21]$.

\section{Animals}

Adult male BALB/c mice ( 6 weeks old, $25 \mathrm{~g}$ ) were provided by the Centro de Investigación Biomédica de Occidente (CIBO-IMSS) and were maintained under standard laboratory condition at $22 \pm 1^{\circ} \mathrm{C}, 55-60 \%$ of humidity, $12 \mathrm{~h} \mathrm{light/dark} \mathrm{cycle} \mathrm{and} \mathrm{food} \mathrm{(Purina} \mathrm{Lab} \mathrm{Chow-México)/water} \mathrm{ad} \mathrm{libitum.} \mathrm{All} \mathrm{experiments} \mathrm{were}$ conducted according to the protocols approved by the NOM-062-ZOO-1999 [22].

\section{Antitumoral Effect}

Animals were randomized in four groups $(n=5)$, and each one was inoculated intraperitoneally with 2 $\mathrm{x} 10^{4} \mathrm{~L} 5178 \mathrm{Y}$ lymphoma cells (in $0.1 \mathrm{~mL}$ of isotonic saline solution) on day zero. Group one was considered the negative control (without treatment). After $24 \mathrm{~h}$; the other groups were treated with cyclophosphamide at $75 \mathrm{mg} / \mathrm{kg}$ by intraperitoneal (i.p.) route during three days (group two), and with bikaverin at $1.73 \mathrm{mg} / \mathrm{kg} / \mathrm{day}$ by i.p. (group three) and oral (group four) administration during 15 days. Afterward, the animals were sacrificed and the peritoneum was washed three times with physiologic saline solution, and the ascitic fluid containing the L5178Y lymphoma cells was collected. Then, $10 \mu \mathrm{L}$ of the diluted cell suspension was placed on the Neubauer chamber, and the cells were counted. The cell viability was determined by trypan blue assay. The antitumoral effect of bikaverin was assessed by observation of changes with regard to the following parameters: tumor weight (weight variation), ascitic fluid volume and cell density.

\section{Statistical Analysis}

Data was statistically analyzed by one-way analysis of variance (ANOVA) followed by Dunnett's multiple comparisons test using the GraphPad Prism software (Version 6.0). $p$ values $<0.05$ were considered to indicate statistical significance.

\section{Results and discussion}

Bikaverin was produced by G. fujikuroi fungus in a bioreactor and extracted as previously described [18]. The crude ethyl acetate extract from the biomass was fractioned by column chromatography, and the fractions with bikaverin were recrystallized to obtain the pure compound. The compound was identified by direct comparison with the spectroscopic data of an authentic sample and data described in the literature. The ${ }^{1} \mathrm{H}-\mathrm{NMR}$ spectrum showed twelve protons attached to carbon atoms: $\delta 3.02(3 \mathrm{H}, \mathrm{s}, 1-\mathrm{Me}), \delta 4.17(3 \mathrm{H}, \mathrm{s}, 8-$ $\mathrm{OMe}), \delta 4.19(3 \mathrm{H}, \mathrm{s}, 3-\mathrm{OMe}), \delta 6.83(1 \mathrm{H}, \mathrm{s}, \mathrm{H}-9), \delta 7.36(1 \mathrm{H}, \mathrm{s}, \mathrm{H}-2)$ and $\delta 7.43(1 \mathrm{H}, \mathrm{s}, \mathrm{H}-4)$. The ${ }^{13} \mathrm{C}-\mathrm{NMR}$ spectrum showed signals due to the aromatic methyl group at $\delta 23.3(1-\mathrm{Me})$, methoxy groups at $\delta 57.5(3-\mathrm{OMe})$ and $\delta 58.0(8-\mathrm{OMe})$ as well as three carbons directly bonded to hydrogen at $\delta 100.1(\mathrm{CH}-4), \delta 109.3(\mathrm{CH}-9)$ 
and $\delta 124.2(\mathrm{CH}-2)$. The NMR spectral data was identical to those of bikaverin previously reported [11,23,24]. Thus, the compound was identified as bikaverin (Fig. 1.).<smiles>COC1=CC(=O)c2c(c(O)c3oc4cc(OC)cc(OC)c4c(=O)c3c2O)C1=O</smiles>

Fig. 1. Chemical structure of bikaverin

Bikaverin was evaluated against the L5178Y lymphoma cells at various concentrations $(0.125$ to 1 $\mu \mathrm{g} / \mathrm{mL}$ ) to determine its cytotoxic effect. The results showed that the cells were sensitive to the bikaverin treatment in a dose-dependent manner. The compound showed a significant cytotoxic effect with an $\mathrm{IC}_{50}$ value of $0.23 \mu \mathrm{g} / \mathrm{mL}$ while cyclophosphamide (positive control) showed an $\mathrm{IC}_{50}$ value of $11 \mu \mathrm{g} / \mathrm{mL}$ (Fig. 2.).

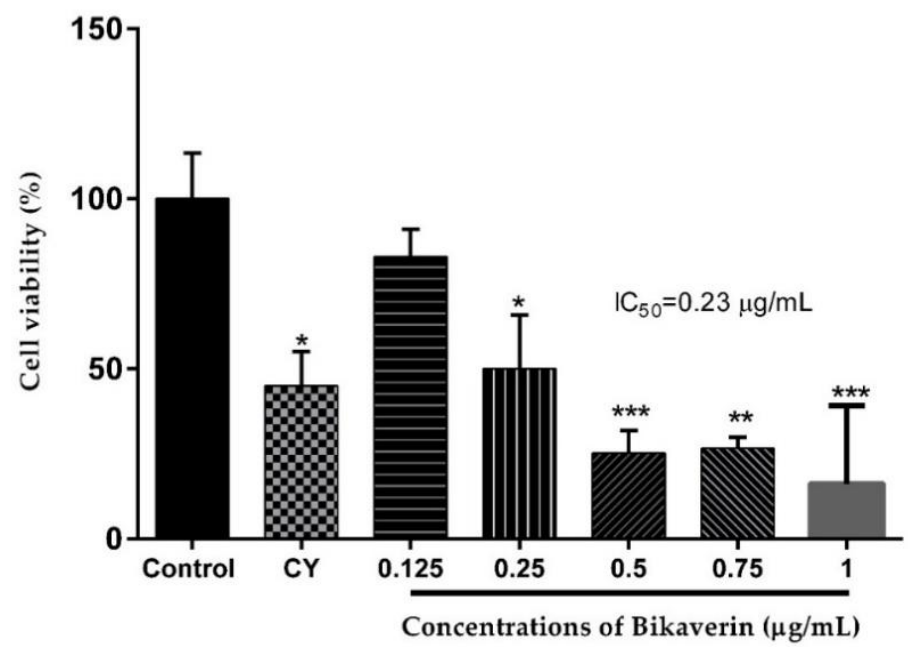

Fig. 2. Cytotoxic effect of bikaverin on L5178Y lymphoma cells. The values are represented as mean \pm S.D of three independent experiments $(n=3)$. Significance was determined using ANOVA followed by Dunnett's multiple comparisons test. Bikaverin and cyclophosphamide (CY) were compared with control group $\left(^{*} p<\right.$ $0.05 ; * *<<0.01 ; * * * p<0.001)$.

The $\mathrm{LD}_{50}$ for laboratory animals was determined in the ProTox web server. According to the oral toxicity prediction, the value of $\mathrm{LD}_{50}$ for bikaverin was $16 \mathrm{mg} / \mathrm{kg}$, which corresponds to class II toxicity compounds $\left(\mathrm{LD}_{50}\right.$ with $5 \leq 50 \mathrm{mg} / \mathrm{kg}$ ). This value is important for future experiments such as antitumoral activity evaluation in order to establish the therapeutic dose in mice. 
Bikaverin at $1.73 \mathrm{mg} / \mathrm{kg} /$ day was evaluated on L5178Y lymphoma murine model to assess the antitumoral effect by either i.p. (group three) or oral (group four) administration. The parameters such as the tumor weight (weight variation), ascitic fluid volume and cell density were analyzed. The results showed that the control group (without treatment) had a weight variation of $4.25 \pm 1.03 \mathrm{~g}$ while the groups treated with bikaverin reduced the weight variation significantly, and showed $1.5 \pm 0.57 \mathrm{~g}$ (i.p.) and $1.2 \pm 0.36 \mathrm{~g}$ (oral), respectively (Fig. 3A). On other hand, in the groups treated with bikaverin, the ascitic fluid volume and cell density were reduced significantly. In this context, the control group showed $3.43 \pm 0.78 \mathrm{~mL}$ of ascitic fluid and bikaverin groups showed $1.1 \pm 0.79 \mathrm{~mL}$ (i.p.) and $0.84 \pm 0.6 \mathrm{~mL}$ (oral), respectively (Fig. 3B). Finally, the cell density in mice without treatment (control) was $1,280 \pm 128 \times 10^{5}$ cells $/ \mathrm{mL}$ and the groups treated with bikaverin showed $391.5 \pm 237 \times 10^{5}$ cells $/ \mathrm{mL}$ (i.p.) and $580 \pm 208 \times 10^{5}$ cells $/ \mathrm{mL}$ (oral), respectively (Fig. 3C). The in vivo study results showed that bikaverin had a significant antitumoral effect on L5178Y lymphoma in mice and were consistent with the in vitro study results.

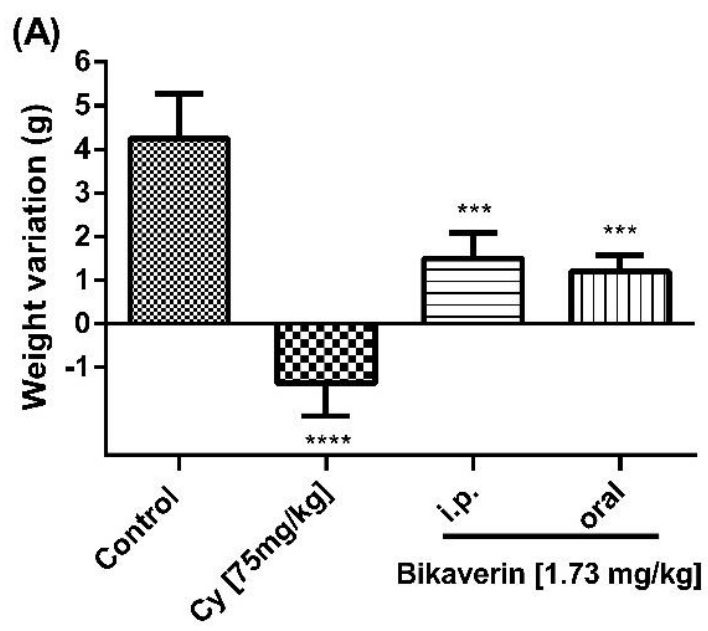

(B)

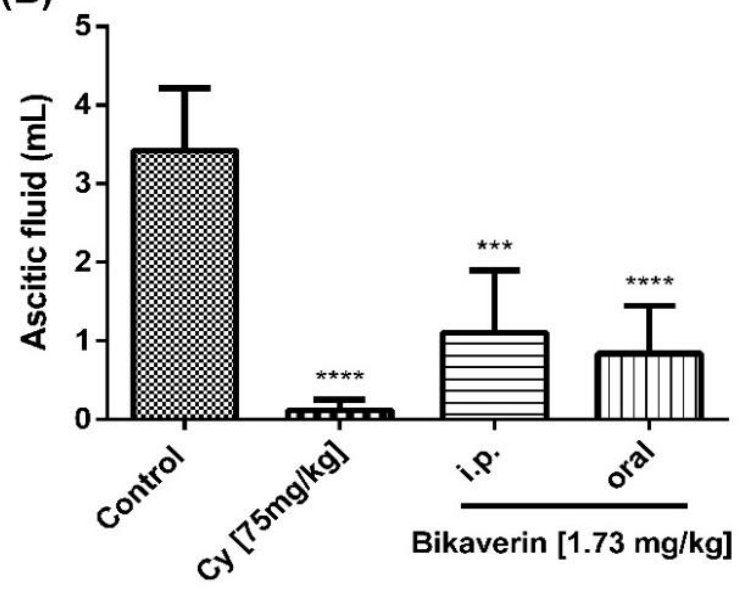




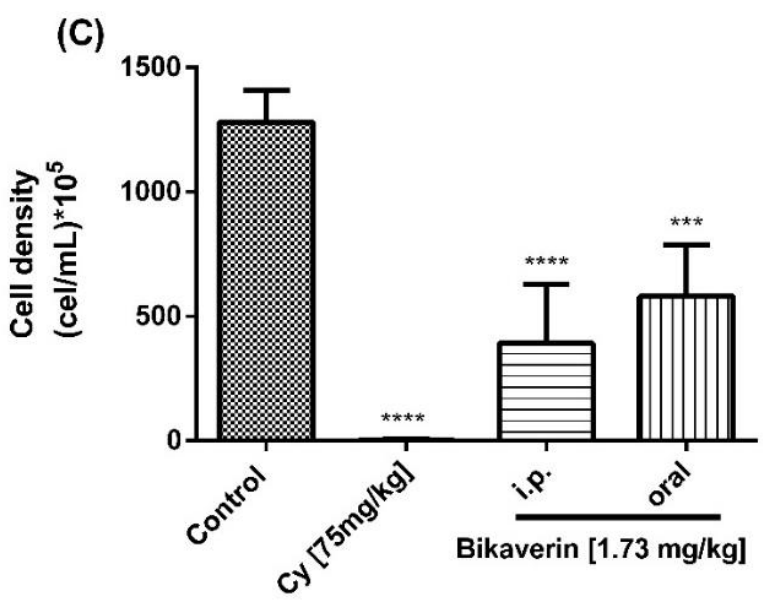

Fig. 3. Antitumoral effect of bikaverin on L5178Y lymphoma murine model by weight variation (3A), ascitic fluid volume (3B) and cell density (3C). The values are presented as mean \pm S.D $(n=5)$. Significance was determined using ANOVA followed by Dunnett's multiple comparisons test. Bikaverin and cyclophosphamide (Cy) were compared with control group $(* * * p<0.001$; **** $\mathrm{p}<0.0001)$.

Bikaverin has gained the attention of researchers for its advantageous biological effects such as antiprotozoal, antifungal, nematicidal, neuroprotective and cytotoxic effect $[8,13]$. About the last, bikaverin and its derivatives have been effective against the following tumor cell lines: Ehrlich ascites carcinoma $\left(\mathrm{ED}_{50}=0.5\right.$ $\mu \mathrm{g} / \mathrm{mL})$, leukemia L5178 $\left(\mathrm{ED}_{50}=1.4 \mu \mathrm{g} / \mathrm{mL}\right)$ and sarcoma $\left(\mathrm{ED}_{50}=4.2 \mu \mathrm{g} / \mathrm{mL}\right)$ [16]. It has been shown that bikaverin inhibits ATP synthesis and, hence, energy metabolism in Ehrlich ascites tumor cells [14]. Also, it was considered an uncoupler of oxidative phosphorylation in tumor cell line P388 [15]. The effect of bikaverin on respiration was reexamined in isolated rat liver mitochondria, and the results showed that the uncoupling effect was only produced at high concentrations as a consequence of disturbing ion permeability of the mitochondrial inner membrane, and at low concentration, bikaverin repressed NAD- and succinate-linked respirations, but did not interfere with electron transport and energy transfer systems of mitochondria [8,25]. Also, the cytotoxic effect of bikaverin has been evaluated against a panel of four human tumor cell lines, non-small cell lung (NCI$\mathrm{H} 460, \mathrm{IC}_{50}=0.43 \mu \mathrm{M}$ ), pancreatic (MIA Pa Ca-2, $\mathrm{IC}_{50}=0.26 \mu \mathrm{M}$ ), breast (MCF-7, $\mathrm{IC}_{50}=0.42 \mu \mathrm{M}$ ) and CNS glioma (SF-268, $\mathrm{IC}_{50}=0.38 \mu \mathrm{M}$ ) [17]. Recently, bikaverin was evaluated in human protein kinase (casein kinase 2 ; CK2) activity and showed inhibitory effect with an $\mathrm{IC}_{50}$ value of $1.24 \mu \mathrm{M}$. This enzyme is implicated in many cellular processes and is highly expressed and active in many tumor cells. CK2 enhances cancer phenotype by suppressing apoptosis and stimulating cell growth. For this reason, the inhibition of CK2 is important to induce the physiological process of apoptosis, leading to tumor cell death [26]. In addition, bikaverin was not genotoxic and cytotoxic in primary rat hepatocytes at low concentrations $(<100 \mu \mathrm{M})$ and had not affect the cell viability on differentiated intestinal porcine epithelial cells (IPEC-J2) at 5-10 $\mu \mathrm{M}[27,28]$.

In this research, the cytotoxic effect of bikaverin was tested on L5178Y lymphoblast and showed an $\mathrm{IC}_{50}$ value of $0.23 \mu \mathrm{g} / \mathrm{mL}$. This result supports the cytotoxic effect of bikaverin against tumor cell lines and shows its pharmacological importance because cytotoxic compounds with an $\mathrm{IC}_{50}$ lower than $4 \mu \mathrm{g} / \mathrm{mL}$ are considered promising for the research of new anticancer agents [29]. For the in vivo model, the $\mathrm{LD}_{50}(16 \mathrm{mg} / \mathrm{kg})$ was determined in silico using the PROTOX software and was reduced approximately 10 times considering the solubility of bikaverin. Thus, a dose of $1.73 \mathrm{mg} / \mathrm{kg} / \mathrm{day}$ of bikaverin was administered by i.p. and oral administration to the mice BALB/c inoculated with L5178Y lymphoma cells. The results showed that bikaverin inhibited significantly the tumor development (weight variation, ascitic fluid, and cell density). Although the cytotoxic effect of bikaverin has been reported, this is the first time that the antitumoral effect (in vivo) of bikaverin is reported and the results show the potential of bikaverin as an antitumoral compound. The 
aforementioned is important because other factors are present in the in vivo model. For example, the compound could be altered in the in vivo model by metabolism and lose its effect. In addition, other key pharmacokinetic parameters such as tissue uptake, bioavailability, absorption and distribution could affect the antitumoral effect of the compound in an organism. Finally, to continue the studies, chemical derivatives of bikaverin could be prepared and their effect tested by structure-activity relationship studies on protein kinase CK2 and cancer cell lines. With regard to the in vivo model, pharmacokinetics, pharmacodynamics and toxicology studies are necessary.

\section{Conclusion}

Natural products are relevant to drug discovery, and fungi is a valuable source of novel compounds that could be used to develop new drugs to the treatment of diseases. In this research, we determined experimentally that bikaverin isolated from $G$. fujikuroi is cytotoxic on L5178Y lymphoblast at low concentrations in a dose-dependent manner, and it showed potential as an antitumoral compound in mice by either i.p. or oral administration. Our in vitro and in vivo results suggest that bikaverin could be considered a promising compound to the development of new anticancer agents.

\section{Acknowledgments}

The authors acknowledge financial support from Consejo Nacional de Ciencia y Tecnología (CONACyT). Gabriela Hinojosa-Ventura is grateful to CONACYT for the scholarship No.384023.

\section{References}

1. Bray, F.; Ferlay, J.; Soerjomataram, I.; Siegel, R. L.; Torre, L. A.; Jemal, A. CA: Cancer J. Clin. 2018, 68, 394-424.

2. Roodhart, J. M. L.; Daenen, L. G. M.; Stigter, E. C. A; Prins, H. J.; Gerrits, J.; Houthuijzen, J. M.; Gerritsen, M. G.; Schipper, H. S.; Backer, M. J. G.; van Amersfoort, M.; Vermaat, J. S. P.; Moerer, P.; Ishihara, K.; Kalkhoven, E.; Beijnen, J. H.; Derksen, P. W. B.; Medema, R. H.; Martens, A. C.; Brenkman, A. B.; Voest, E. E. Cancer Cell 2011, 20, 370-383.

3. Atmaca, H.; Çamli, C.; Sert, S. Celal Bayar University Journal of Science 2018, 14, 35-40.

4. Newman, D. J.; Cragg, G. M. J. Nat. Prod. 2016, 79, 629-661.

5. Espinoza, C.; Couttolenc, A.; Fernández, J. J.; Norte, M.; Plata, G. B.; Padrón, J. M.; Shnyreva, A.; Trigos, A. J. Mex. Chem. Soc. 2016, 60, 79-82.

6. Bugni, T. S.; Ireland, C. M. Nat. Prod. Rep. 2004, 21, 143-163.

7. Kharwar, R. N.; Mishra, A.; Gond, S. K.; Stierle, A.; Stierle, D. Nat. Prod. Rep. 2011, 28, 1208-1228.

8. Limón, M. C.; Rodríguez-Ortiz, R.; Avalos, J. Appl. Microbiol. Biotechnol. 2010, 87, 21-29.

9. Schumacher, J.; Gautier, A.; Morgant, G.; Studt, L.; Ducrot, P.-H.; Le Pêcheur, P.; Azeddine, S.; Fillinger, S.; Leroux, P.; Tudzynski, B.; Viaud, M. PloS One. 2013, 8, e53729-e53742.

10. Balan, J.; Fuska, J.; Kuhr, I.; Kuhrová, V. Folia Microbiol. 1969, 15, 479-484.

11. Son, S. W.; Kim, H. Y.; Choi, G. J.; Lim, H. K.; Jang, K. S.; Lee, S. O.; Lee, S.; Sung, N. D.; Kim, J.C. J. Appl. Microbiol. 2008, 104, 692-698.

12. Kwon, H. R.; Son, S. W.; Han, H. R.; Choi, G. J.; Jang, K. S.; Choi, Y. H.; Lee, S.; Sung, N. D.; Kim, J.-C. Plant Pathol. J. 2007, 23, 318-321.

13. Nirmaladevi, D.; Venkataramana, M.; Chandranayaka, S.; Ramesha, A; Jameel, N. M.; Srinivas, C. Cell. Mol. Neurobiol. 2014, 34, 973-985.

14. Henderson, J. F.; Battell, M. L.; Zombor, G.; Fuska, J.; Nemec, P. Biochem. Pharmacol. 1977, 26, 1973-1977. 
15. Kovac, L.; Bohmerova, E.; Fuska, J. J. Antibiot. 1978, 31, 616-620.

16. Fuska, J.; Proksa, B.; Fusková, A. Neoplasma. 1975, 22, 335-338.

17.Zhan, J.; Burns, A. M.; Liu, M. X.; Faeth, S. H.; Gunatilaka, A. A. L. J. Nat. Prod. 2007, 70, 227-232.

18. Chavez-Parga, M. C.; Hinojosa-Ventura, G.; Maya-Yescas, R.; Gonzalez-Hernandez, J. C. Int. Rev. Chem. Eng. 2014, 6, 100-107.

19. Navarro-Salcedo, M. H.; Delgado-Saucedo, J. I.; Siordia-Sánchez, V. H.; González-Ortiz, L. J.; Castillo-Herrera, G. A.; Puebla-Pérez, A. M. J. Med. Food. 2017, 20, 1076-1082.

20. http://tox.charite.de/tox/index.php?site=compound_search_similarity (accessed on November 16, 2017).

21. Banerjee, P.; Erehman, J.; Gohlke, B.-O.; Wilhelm, T.; Preissner, R.; Dunkel, M. Nucleic Acids Res. 2015, 43, D935-D939.

22. Secretaría de Agricultura Ganadería, Desarrollo Rural, Pesca y Alimentación: Norma Oficial Mexicana NOM-062-ZOO-1999, Especificaciones técnicas para la producción, cuidado y uso de animales de laboratorio, Edited by Diario Oficial de la Federación. 2001.

23. Kjaer, D.; Kjaer, A.; Pedersen, C.; Bu'Lock, J. D.; Smith, J. R. J. Chem. Soc. 1971, 1, 2792-2797.

24. Mcinnes, A. G.; Walter, J. A.; Smith, D. G.; Wright, J. L. C.; Vining, L. C. J. Antibiot. 1976, 29, $1050-1057$.

25. Suzuki, T.; Kitagawa, A.; Kawai, K.; Hamasaki, T. Micotoxin Res. 1998, 14, $19-27$.

26. Haidar, S; Bouaziz, Z.; Marminon, C.; Laitinen, T.; Poso, A.; Le Borgne, M.; Jose, J. Pharmaceuticals. 2017, 10, 1-13.

27. Norred, W. P.; Plattner, R. D.; Vesonder, R. F.; Bacon, C. W.; Voss, K. A. Food Chem. Toxicol. 1992, 30, 233-237.

28. Springler, A.; Vrubel, G.-J.; Mayer, E.; Schatzmayr, G.; Novak, B. Toxins 2016, 8, 345-365.

29. Jacobo-Herrera, N. J.; Jacobo-Herrera, F. E.; Zentella-Dehesa, A.; Andrade-Cetto, A.; Heinrich, M.; Pérez-Plasencia, C. J. Ethnopharmacol. 2016, 179, 391-402. 